\title{
Modeling / Optimization and Effect of Environmental Variables on Energy Production Based on PV / Wind Turbine Hybrid System
}

\author{
Reza Alayi ${ }^{1 *}$, Javad Velayti ${ }^{2}$ \\ ${ }^{1}$ Department of Mechanics, Germi Branch, Islamic Azad University, Germi, Iran \\ ${ }^{2}$ Department of energy engineering, Energy Institute of Higher Education, Saveh, Iran.
}

\begin{tabular}{l} 
ARTICLE INFO \\
\hline Article history: \\
Received April 04, 2021 \\
Revised April 16, 2021 \\
Accepted April 24, 2021 \\
\hline
\end{tabular}

Keywords:

Hybrid Power Plant;

Solar Radiation;

Wind Turbine;

Photovoltaic;

Invests Return Rate

\begin{abstract}
The use of fossil fuels to supply human energy needs is increasing day by day, which contributes to environmental pollution. In addition, they have a limited supply and are not continuously being made, or they are made very slowly. Thus, to reduce human dependence on this type of energy, the use of renewable energy sources is increasing, which has problems because of the high cost of investment and the stochastic nature. In this study, a sensitivity analysis of renewables was conducted to evaluate the impact of these resources on the costs of hybrid power plants based on renewable energies. In this regard, the amount of wind and intensity of sunlight was studied in the Kermanshah region. Significant results can be attributed to a reduction in the rate of return of capital to 9.22 years for the radiation intensity of $4.5 \mathrm{Kwh} / \mathrm{m}^{2} / \mathrm{d}$. Then, by Sensitivity analysis to wind intensity, the Optimal wind turbine speed was 4.99 $\mathrm{m} / \mathrm{s}$, for COE 0.93( $\$ / \mathrm{Kwh})$.
\end{abstract}

This work is licensed under a Creative Commons Attribution-Share Alike 4.0

\section{Reza Alayi,}

Department of Mechanics, Germi Branch, Islamic Azad University, Germi, Iran.

Email: reza.alayi@yahoo.com; reza_alayi@iaugermi.ac.ir

\section{INTRODUCTION}

Given the importance of using renewable energy sources in the energy supply, the use of renewable and endless energy sources is gradually increasing today [1][2][3][4]. Energy experts believe that the use of renewable energy production systems will reduce risks such as reduced fossil fuels and environmental pollution. In addition, fossil fuels such as oil, gas, and coal will eventually come to an end, and civilization that is directly dependent on non renewable energy will end up with a new and larger challenge [5][6][7]. This has led industrialized and developed countries to take more serious action in using other energy sources, particularly renewable energies [8][9][10][11]. The use of solar energy, wind and sea waves, geothermal, hydrogen, biomass, and so-called renewable energies requires a lot of research, and research must be done before use. Renewable energies, especially for developing countries, are more attractive. Therefore, international programs and policies, including those of the United Nations, have been assigned a special role in the context of sustainable global development of renewable energy sources [12][13]. However, there are problems with integrating these systems with current systems. Because of this, extensive research has been done on renewable systems.

Some of the research in this area are mentioned: Elbaz and et al. [12] have provided research titled MultiObjective Optimization Method for Proper Configuration of Grid-Connected PV-Wind Hybrid System in Terms of Ecological Effects, Outlay, and Reliability. Nyeche and et al. [13] have provided research titled Modelling and optimization of a hybrid PV-wind turbine-pumped hydro storage energy system for mini-grid application in coastline communities. Anoune and et al. [14] have provided a research titled Sizing methods and optimization techniques for PV-wind-based hybrid renewable energy system: A review. Mayer and et al. [15] have provided a research titled Environmental and economic multi-objective optimization of a household level hybrid renewable energy system by genetic algorithm. Salameh and et al. [16] have provided research titled Techno-economical optimization of an integrated stand-alone hybrid solar PV tracking and diesel generator power system in Khorfakkan, United Arab Emirates. Alayi and et al. [17][18] Provide research in 
the field of hybrid systems based on renewable energy systems. Adefarati and et al. [19] have provided research titled Techno-economic analysis of a PV-wind-battery-diesel standalone power system in a remote area. Maatallah and et al. [20] have Provide research data in the field of hybrid wind and solar systems. Vasel and et al. [21] have provided research titled the effect of wind direction on the performance of solar PV plants.

In the present study, the impact of these resources on investment cost and rate of return on capital has been investigated in order to prevent unexpected events from decreasing or increasing wind speed and intensity of solar radiation.

\section{RESEARCH METHOD}

Bistoon Thermal Power Plant Iran is located at Shahrak-e-Bistoon, Kermanshah, Iran. It has a design capacity of $640 \mathrm{Mw}$ with two steam units of $320 \mathrm{MW}$ on land with an area of 130 hectares. Location coordinates are: Latitude $=34.3468$, Longitude $=47.3575$. In Fig. 1 and Table 1, the geographical characteristics of this area can be seen. It has a latitude of $37.8^{\circ}$ and a longitude of $45.20^{\circ}$.

Table 1. Geographical characteristics of the studied

\begin{tabular}{cc} 
Parameter & Quantity \\
\hline Latitude & $37.8^{0}$ \\
Longitude & $45.20^{\circ}$ \\
\hline
\end{tabular}

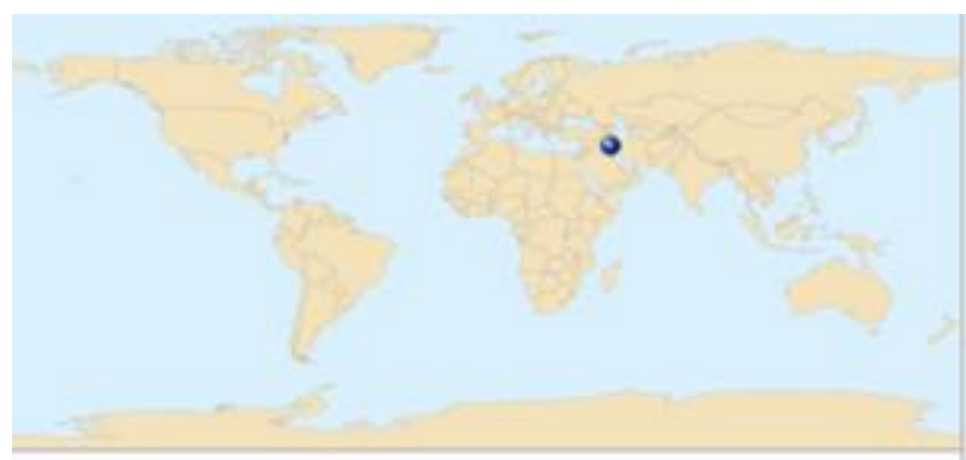

Fig. 1. Geographical specifications of Kermanshah city

\subsection{Solar Radiation}

In this research, information about the intensity of solar radiation in Kermanshah for the years 2017-2018 is taken from NASA and is used as inputs to Homer software. According to this, the amount of average radiation of the sun in this area was $5.08 \mathrm{kWh} / \mathrm{m}^{2} / \mathrm{d}$. the relative diagram can be seen in Fig. 2 .

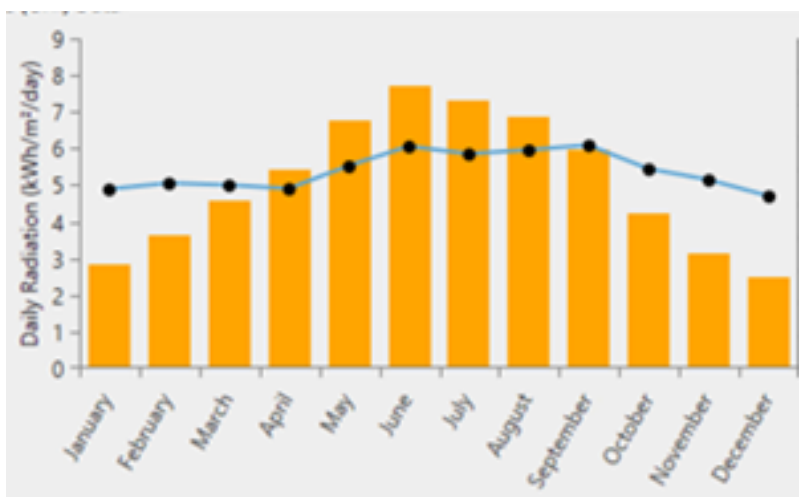

Fig. 2. Daily radiation $\left(\mathrm{Kwh} / \mathrm{m}^{2} /\right.$ day) for the studded site

As can be seen from Fig. 2, the highest intensity of solar radiation is related to the month of June with an average of $7.7 \mathrm{KWh} / \mathrm{m}^{2} /$ day, which reaches its lowest value in the year in December, i.e. $2.3 \mathrm{KWh} / \mathrm{m}^{2} /$ day. 


\subsection{Wind Speed}

In this section, the wind speed has been extracted in the desired site, and the amount of wind at the height of 50 meters can be seen in Fig. 3 for one year. From the chart in Fig. 3, it can be seen that the average wind speed in this region is 4.99 meters per second, which shows the high potential of this region for exploitation. The highest and lowest winds are in July and January, with 5.9 and 4.22 meters per second, respectively. Fig. 2 and Fig. 3, which show the potential of this city to use solar and wind-based technologies.

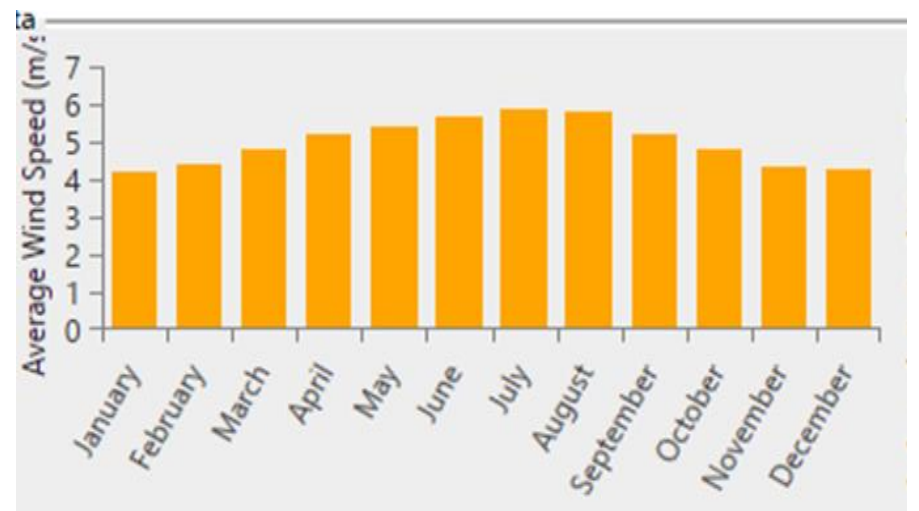

Fig. 3. Average wind speed $\left(\mathrm{m} / \mathrm{s}^{2}\right)$ for the studded site

According to Fig. 3 shows the average wind intensity for different months of the year. The highest average wind intensity is related to the month of July with the value of $5.8 \mathrm{~m} / \mathrm{s}$, while the lowest value is related to the month of January with the value of $4.15 \mathrm{~m} / \mathrm{s}$.

\subsection{Electrical Load}

To simulate more accurately and to achieve more realistic results, the amount of electric load supplied by the power plant is provided. The total amount of electrical load is $24000 \mathrm{kwh} / \mathrm{d}$, and the peak load is $1833 \mathrm{~kW}$, which can be seen in detail in Fig. 4 [http://www.ttbp.ir].

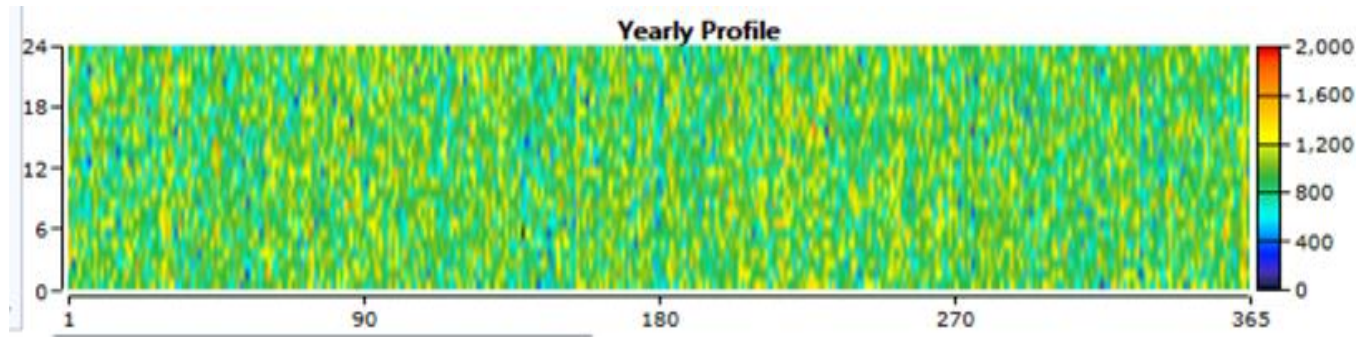

Fig. 4. electric load for Bistoon Thermal Power Plant

\subsection{Model of the System Under Study}

Photovoltaic cells and battery storage systems are connected to the DC load bus. The total output power of these units is connected to the AC bus by a DC / AC converter for consumer use. By applying the information to the software as well as the cost of the tools used in the hybrid system, the configuration can be considered as in Fig. 5.

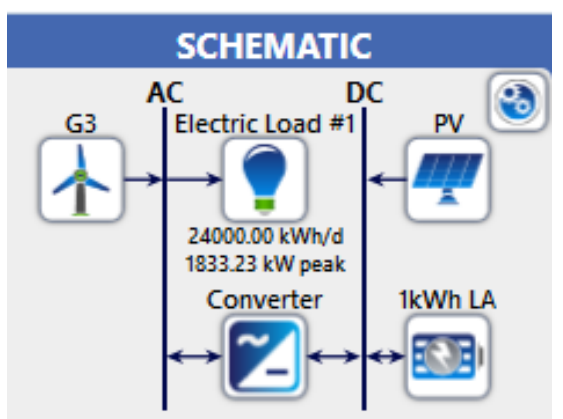

Fig. 5. General schematic of the solar and wind hybrid system with battery storage 
As can be seen from Fig. 5, the system under study consists of equipment such as wind turbine, photovoltaic cells, batteries, and converters. In Table 1, the economic specifications and lifespan of each of these equipment can be seen. For wind turbine and photovoltaic cells, two characteristics of longevity and economic considerations are given, and in addition to the characteristics of longevity and economy in the converter, the amount of efficiency in different modes is also determined.

Table 2. Information on equipment requirements of the system under study

\begin{tabular}{|c|c|c|c|c|}
\hline \multirow{2}{*}{ Equipment } & \multicolumn{3}{|c|}{$\operatorname{Cost}(\$)$} & \multirow{2}{*}{ Other information } \\
\hline & O\&M & Replacement & Capital & \\
\hline G3 & 2600 & 26000 & 130000 & Life time: $20 \mathrm{yr}$ \\
\hline PV & 10 & 3000 & 3000 & Life time: $25 \mathrm{yr}$ \\
\hline Converter & 5 & 300 & 300 & $\begin{array}{c}\text { Derating factor: } 80 \% \\
\text { Life time: } 20 \mathrm{yr} \\
\text { Inverter eff: } 95 \%\end{array}$ \\
\hline Generic $1 \mathrm{kWh}$ Lead Acid & 10 & 300 & 300 & $\begin{array}{c}\text { Rectifier eff: } 90 \% \\
\text { Life time: } 10 \mathrm{yr} \\
\text { Throughput (Kwh): } 800\end{array}$ \\
\hline
\end{tabular}

\section{RESULTS AND DISCUSSION}

\subsection{Sensitivity Analysis on the Intensity of Sunlight}

Considering that the intensity of the sun may vary in the next few years and it changes the mean value, so it can be made to reach the system with high reliability that can be made. Sensitivity analysis was performed on the intensity of the solar radiation is shown in Fig. 6.

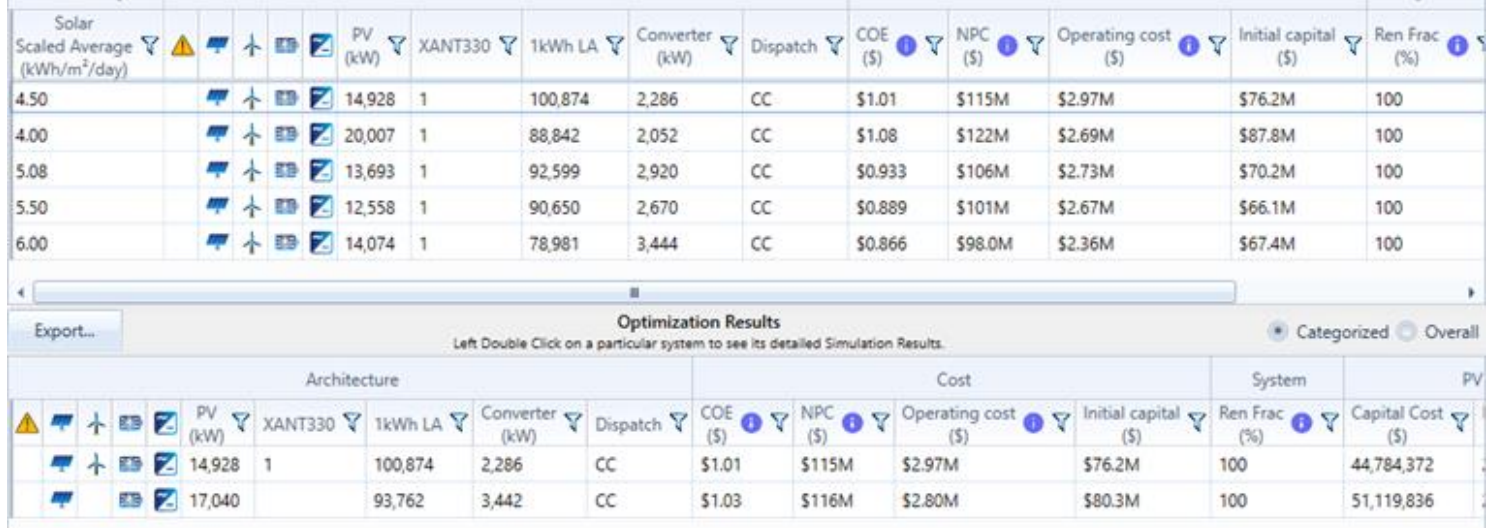

Fig. 6. Results from the sensitivity analysis on the intensity of the solar radiation

In economic analysis, the parameters of Net Percent Cost (NPC) and cost of energy (COE) are very important. Considering two economic indicators and the reliability of the electricity for different cases, the best state of the radiation intensity is $4.5\left(\mathrm{KWh} / \mathrm{m}^{2} /\right.$ day) with the results obtained in Fig. 7.

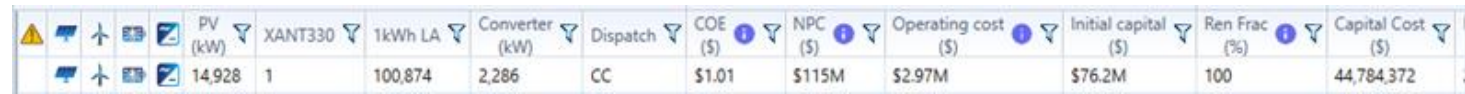

Fig. 7. Results from the sensitivity analysis on the intensity of the solar radiation

As shown in Fig. 7, for a solar radiation of $4.5 \mathrm{KWh} / \mathrm{m}^{2} /$ day, the optimal solar radiation of the system was determined. To provide the required electrical power with the lowest investment cost, the system needs 1 wind turbine and $14928 \mathrm{~kW}$ photovoltaic cells to generate power. To convert power to AC power to $2286 \mathrm{~kW}$ converter with $100874 \mathrm{kVA}$ battery is needed to store excess energy. For the system in Fig. 7, the effective economic indicators in the selection of equipment are listed in Table 3.

As can be seen from Table 3, considering the sensitivity analysis on solar radiation, economic parameters will also change so that for the optimal solar radiation, the rate of return on investment by considering two cases in interest and non-interest costs is 9.50. And 9.22 years. The amount of electric power produced for the intensity of the solar radiation can be observed in Fig. 8. 
Table 3. Economic effective indicators in the selection of mode system equipment

\begin{tabular}{cc} 
Indicator & value $(\mathbf{y r})$ \\
\hline return of capital with no interest & 9.22 \\
return of capital by considering interest & 9.50 \\
\hline
\end{tabular}

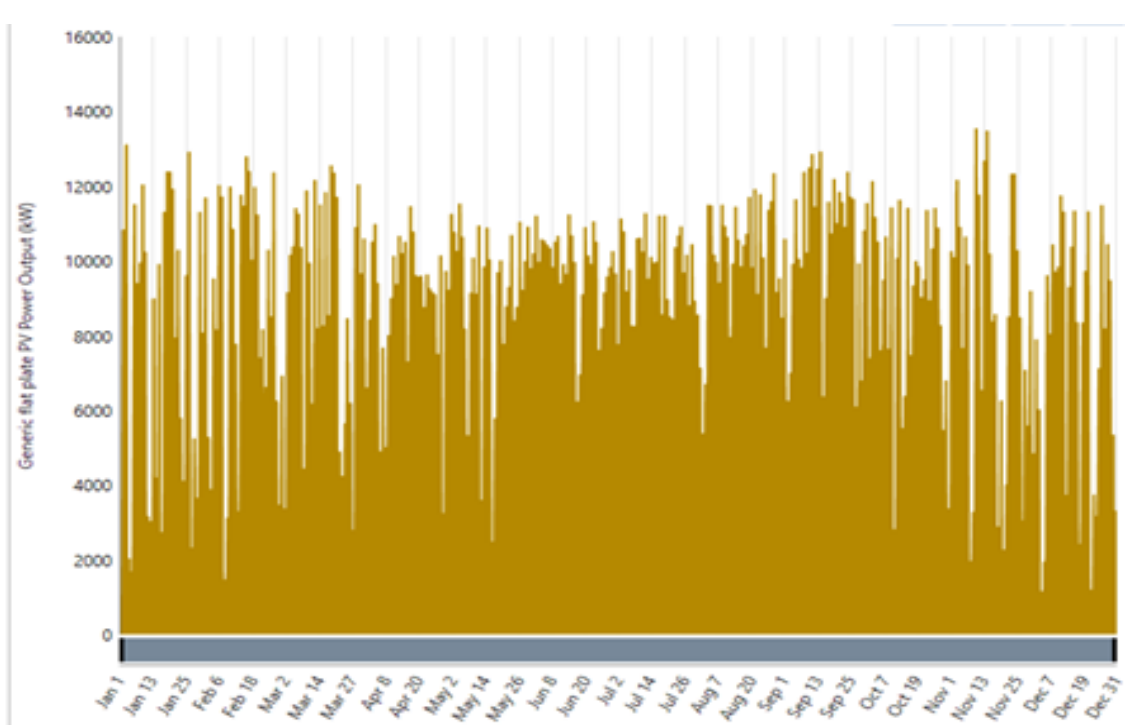

Fig. 8. The amount of power produced by the photovoltaic cell for optimal radiation intensity

\subsection{Sensitivity Analysis of Wind Speed}

Considering that the intensity of the wind may vary in the next few years and it changes the mean value, so it can be made to reach the system with high reliability that can be made. Sensitivity analysis was performed on the intensity of the wind. Considering two economic indices and the reliability, reliability of various states, the best state corresponds to the mean density of $4.99 \mathrm{~m} / \mathrm{s}$ with the results obtained in Fig. 9.

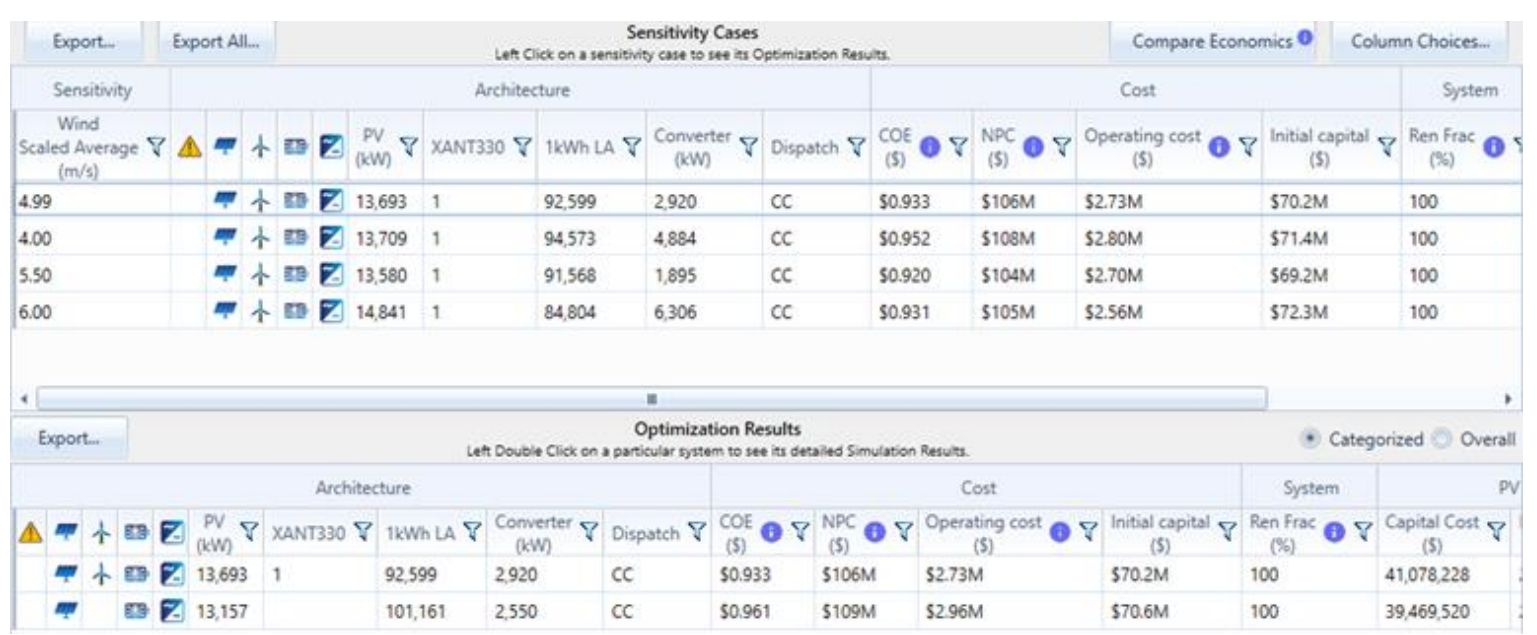

Fig. 9. Results from sensitivity analysis on the severity of the wind

According to Fig. 9, which has different wind speeds for the studied system, the optimal wind intensity in terms of two economic elements and maximum production capacity is related to the value of $4.99 \mathrm{~m} / \mathrm{s}$, which is considered as the wind speed. Input to the turbine The amount of investment cost and the amount of production capacity of the whole system can be seen in Fig. 10.

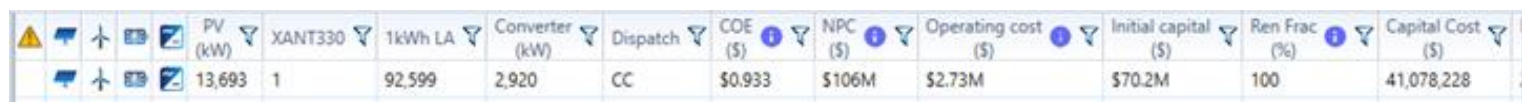

Fig. 10. Results from sensitivity analysis for the most optimal wind intensity 
As shown in Fig. 10, for a wind speed of 4.99, the optimal wind speed of the system was determined. To provide the required electrical power with the lowest investment cost, the system needs 1 wind turbine and $13693 \mathrm{~kW}$ photovoltaic cells to generate power. To convert power to AC power to $2920 \mathrm{~kW}$ converter with $92599 \mathrm{kVA}$ battery is needed to store excess energy. For the system in Fig. 10, the effective economic indicators in the selection of equipment are listed in Table 4.

Table 4. Economic effective indicators in the selection of mode system equipment

\begin{tabular}{cc} 
Indicator & value $(\mathbf{y r})$ \\
\hline return of capital with no interest & 9.01 \\
return of capital by considering interest & 9.12 \\
\hline
\end{tabular}

As can be seen from Table 4, considering the sensitivity analysis on wind intensity, economic parameters will also change so that for the optimal wind intensity, the rate of return on investment by considering two cases in interest and non-interest costs is 9.12. And 9.01 years.

\section{CONCLUSION}

In the present study, the impact of these resources on investment cost and rate of return on capital has been investigated in order to prevent unexpected events from decreasing or increasing wind speed and intensity of solar radiation. After a sensitivity analysis, the optimum intensity of the radiation to obtain the lowest cost of the radiation intensity was $4.5\left(\mathrm{KWh} / \mathrm{m}^{2} /\right.$ day $)$. In order to achieve the highest efficiency, the highest intensity of radiation is the most optimum. Considering the two economic indices and the reliability of a power system for different states, the best condition for the average blowing intensity of blowing meter per second was achieved. According to the economic results, the highest cost component of batteries can be considered as a cost-saving technology, which has a significant role in the total economic cost.

\section{REFERENCES}

[1] R. Alayi, A.B. Kasaeian, F. Atabi, "Thermal analysis of parabolic trough concentration photovoltaic/thermal system for using in buildings," Environmental Progress \& Sustainable Energy, Vol. 38, 13220, 2019. https://doi.org/10.1002/ep.13220

[2] R. Alayi, A.B. Kasaeian, F. Atabi, "Optical modeling and optimization of parabolic trough concentration photovoltaic/thermal system," Environmental Progress \& Sustainable Energy, Vol. 39, 13303, 2020. https://doi.org/10.1002/ep.13303

[3] T. Güney, "non-renewable energy and sustainable development," International Journal of Sustainable Development \& World Ecology, Vol. 26, pp.389-397, 2019. https://doi.org/10.1080/13504509.2019.1595214

[4] R. Alayi, H. Harasii, H. Pourderogar, H. "Modeling and optimization of photovoltaic cells with GA algorithm," Journal of Robotics and Control (JRC), Vol. 2, pp. 35-41, 2021. https://doi.org/10.18196/jrc.2149

[5] R. Alayi, M.R.B. Khan, M.S.G. Mohmammadi, "Feasibility study of grid-connected PV system for peak demand reduction of a residential building in Tehran, Iran," Mathematical Modelling of Engineering Problems, Vol. 7, pp.563-567, 2020. https://doi.org/10.18280/mmep.070408

[6] R. Alayi, et al, "Energy, environment and economic analyses of a parabolic trough concentrating photovoltaic/thermal system, " International Journal of Low-Carbon Technologies, ctaa086, 2020. https://doi.org/10.1093/ijlct/ctaa086

[7] R. N. Wojuola, B. P. Alant, "Sustainable development and energy education in Nigeria," Renewable energy, Vol. 139, pp. 1366-1374, 2019. https://doi.org/10.1016/j.renene.2019.03.010

[8] R. Alayi, et al, "Technical and environmental analysis ofphotovoltaic and solar water heatercogeneration system: a case study of SavehCity," International Journal of Low-Carbon Technologies, ctaa077, 2020. https://doi.org/doi:10.1093/ijlct/ctaa077

[9] M. M. Tun, "An overview of renewable energy sources and their energy potential for sustainable development in Myanmar," European Journal of Sustainable Development Research, Vol. 3, em0071, 2019. https://doi.org/10.20897/ejosdr/3951

[10] A. K. Whitcraft, I. Becker-Reshef, C. O. Justice, L. Gifford, A. Kavvada, I. Jarvis, "No pixel left behind: Toward integrating Earth Observations for agriculture into the United Nations Sustainable Development Goals framework," Remote Sensing of Environment, Vol. 235, 111470, 2019. https://doi.org/10.1016/j.rse.2019.111470

[11] E. C. Pischke, et al, "From Kyoto to Paris: measuring renewable energy policy regimes in Argentina, Brazil, Canada, Mexico and the United States," Energy Research \& Social Science, Vol. 50, pp. 82-91, 2019. https://doi.org/10.1016/j.erss.2018.11.010 
[12] A. Elbaz, M.T. Guneser, "Multi-Objective Optimization Method for Proper Configuration of Grid-Connected PVWind Hybrid System in Terms of Ecological Effects, Outlay, and Reliability," Journal of Electrical Engineering \& Technology, Vol. 16, No. 2, pp. 771-782, 2021. https://doi.org/10.1007/s42835-020-00635-y

[13] E. N. Nyeche, E.O. Diemuodeke, "Modelling and optimisation of a hybrid PV-wind turbine-pumped hydro storage energy system for mini-grid application in coastline communities," Journal of cleaner production, Vol.250, 119578,2020. https://doi.org/10.1016/j.jclepro.2019.119578

[14] K.Anoune, M. Bouya, A. Astito, A.B. Abdellah, "Sizing methods and optimization techniques for PV-wind based hybrid renewable energy system: A review," Renewable and Sustainable Energy Reviews,vol.93, pp. 652-673, 2018. https://doi.org/10.1016/j.rser.2018.05.032

[15] M. J. Mayer, A. Szilágyi, G. Gróf, "Environmental and economic multi-objective optimization of a household level hybrid renewable energy system by genetic algorithm," Applied Energy, Vol. 269, 115058, 2020. https://doi.org/10.1016/j.apenergy.2020.115058

[16] T. Salameh, C. Ghenai, A. Merabet, M. Alkasrawi, "Techno-economical optimization of an integrated stand-alone hybrid solar PV tracking and diesel generator power system in Khorfakkan, United Arab Emirates," Energy, vol. 190, 116475, 2020. https://doi.org/10.1016/j.energy.2019.116475

[17] R. Alayi, H. Rouhi, "Techno-Economic Analysis of Electrical Energy Generation from Urban Waste in Hamadan, Iran," International Journal of Design \& Nature and Ecodynamics, Vol. 15, pp.337-341, 2020. https://doi.org/10.18280/ijdne.150307

[18] R. Alayi, A.B. Kasaeian, A. Najafi, A. E. Jamali, "Optimization and evaluation of a wind, solar and fuel cell hybrid system in supplying electricity to a remote district in national grid", International Journal of Energy Sector Management, Vol. 14, pp. 408-418, 2019. https://doi.org/10.1108/JJESM-04-2019-0019

[19] T.Adefarati, R.C. Bansal, J.J. Justo, "Techno-economic analysis of a PV-wind-battery-diesel standalone power system in a remote area," The Journal of Engineering, vol. 2017. No. 13, pp. 740-744., 2017. https://doi.org/10.1049/joe.2017.0429

[20] T. Maatallah, N. Ghodhbane, S. B. Nasrallah, "Assessment viability for hybrid energy system (PV/wind/diesel) with storage in the northernmost city in Africa, Bizerte, Tunisia," Renewable and Sustainable Energy Reviews, Vol. 59, pp. 1639-1652, 2016. https://doi.org/10.1016/j.rser.2016.01.076

[21] A. Vasel, F. Iakovidis, F. "The effect of wind direction on the performance of solar PV plants," Energy Conversion and Management, Vol. 153, pp. 455-461, 2017. https://doi.org/10.1016/j.enconman.2017.09.077

\section{BIOGRAPHY OF AUTHORS}

Reza Alayi currently works at the Department of Mechanical Engineering, Islamic Azad University Germi Branch. Research interests can be cited as renewable energy (Solar and Wind)-energy management in buildings and industry.

Javad Velayti currently works at the Department of energy engineering, Energy Institute of Higher Education, Saveh, Iran. 